walls and the exhaust valve during the exhaust stroke, and has therefore been extracted from the working fluid before it reaches the calorimeter (Scientific Papers, pp. 272 and 288).

This would, of course, yield a very high value for $x$-much higher than I should have thought possible. It is right, however, to add that although Hopkinson's experiments relate to the same engine and are given in the same paper, he does not appear to have correlated the two sets of figures. But even so, after making large allowance for possible experimental error, we are still left with a value for $x$ which suggests its very real practical importance.

Engineering Department,

The University, Leeds, Feb. 24.

\section{Australian Origin of Red Rain in New Zealand.}

WE have recently had two striking examples of the manner in which the influence of a continent may extend, in ways which might easily be overlooked, to enormous distances round about it. It is well known that in dry years large quantities of smoke from bush fires in Australia are carried by the south-east monsoon over the East Indian Archipelago. On Oct. 25 and 26, 1929, however, dense haze, which can have had none other than an Australian origin, was seen at the Island of Niue in lat. $19^{\circ}$ S., long. $170^{\circ}$ W., 2300 miles distant from Australia. The meteorological observer, Mr. J. P. McMahon-Box, reports that "A strange smoky haze enveloped the whole Island on the 25 th and 26th. It came up about midnight on the 24th to 25th, apparently from the south-west, in which direction it was densest. Visibility was very poor indeed. . . . It disappeared during the night of the 26 th to $27 \mathrm{th}$. . . . We experienced a couple of thunderstorms during the period of the haze."

On reference to the weather charts, it is found that on the morning of Oct. 22 a rather intense anticyclone was centred just west of Tasmania, while a deep cyclone had developed in the Tasman Sea. Strong south-west or southerly winds were blowing over eastern Australia, where there had been little rain. It is probable that dense masses of bush-fire smoke mixed with fine dust started on the journey to Niue on that day. During the following days the cyclone moved eastward, its track curving round to the north of New Zealand. At 9 A.M. (New Zealand time) on Oct. 24 its centre was in about $32^{\circ} \mathrm{S}$. and $178^{\circ} \mathrm{E}$., the pressure being below $29 \cdot 10$ inches. The strong west to south winds in the north-west quadrant of the cyclone made conditions ideal for the transport of dust and smoke from Australia to the Pacific Islands. It is worth noting that thunderstorms were reported near the centre of the cyclone on both Oct. 22 and 24 , when vessels happened to be favourably situated.

The second phenomenon was recorded in Nèw Zealand on Nov. 27, when copious deposits of red dust, such as is found in the interior of Australia, were brought down by rain over a wide area covering the Marlborough, Nelson, and Taranaki Provinces, and the portion of the Wellington Province lying to the west of the mountain ranges. Flowers, washing, motor-cars, etc., were stained a pale chocolate colour. Many observers noted that the clouds had a reddishbrown appearance and some severe thunderstorms occurred. Several samples of the dust were sent to the Meteorological Office. Another interesting sample was forwarded by $\mathrm{Mr}$. A. C. Jones, the second officer of the M.S. Taranaki. This was found adhering to damp structures on the vessel when 190 miles from the Australian coast on Nov. 23. The vessel was in dust haze when between the following positions, $39^{\circ} 43^{\prime}$ S., $151^{\circ} 4^{\prime}$ E., and $39^{\circ} 56^{\prime}$ S., $152^{\circ} 43^{\prime} \mathrm{E}$.

On this occasion again the dust was brought to New Zealand by the winds in the north-west quadrant of a complicated depression which moved across the Tasman Sea between Nov. 23 and 28. This depression was at first of the inverted- $V$ type, but afterwards two cyclonic centres developed in the northern portion. One of these disappeared, and by Nov. 27 a deep cyclone was centred off the south -west coast of the Dominion.

At Reefton, in the Nelson Province, a slight sediment was left by the rain on Sept. 4, 1929.

The most notable deposit of dust from Australia on New Zealand occurred, however, on Oct. 6-10, 1928, and is described in papers by Dr. P. Marshall and myself in the New Zealand Journal of Science and Technology, vol. 10, No. 5, pp. 291-99; 1929. Following on that occurrence the snow for many miles, probably 200 to 300 , along the main ranges of the South Island, was for months stained a pale chocolate colour. On Ben Lomond, near Queenstown, in Otago, at the end of October, I found the snow impregnated with the dust in a layer about five inches thick. From the amount of snow I was able to carry away in a hand. kerchief, more than 4 grams of deposit were collected. 200,000 tons is a conservative estimate for the weight of the total deposit on New Zealand in this fall. On this occasion, also, thunderstorms were numerous and very violent, and it seems certain that the suspended dust is, in part at least, responsible for their development.

It will be seen that dust storms of the nature described may, in the course of time, be responsible for a red sediment of no inconsiderable thickness on the floors of the Tasman Sea and the Pacific Ocean.

Meteorological Office, Wellington, EDWARD KIDSON. Dec. 27, 1929 .

THE sample of red rain dust collected at Ben Lomond, near Queenstown in southern New Zealand, by Dr. Kidson, which the Editor has kindly sent me for inspection, agrees in its microscopic characters with falls previously described. It contains some coarse quartz grains, doubtless of local origin, but the bulk is a fine clay and silt such as is common on the dry lake beds of the interior of Australia; it contains some diatoms and shreds of algæ, which look like those that grow in the pools in such localities.

The red rain that falls in Victoria acts as an indelible stain on fresh paint, and that which fell on Feb. 14, 1903 , was proved by F. Chapman and H. J. Grayson (Vict. Naturalist, vol. 20, pp. 17-32, pl. i, ii ; 1903) from the diatoms to be derived "from the swamps and salt-lakes which fringe the River Murray and its tributaries " and from other rivers in South Australia. These authors proved the same origin for some material which I obtained in southern New Zealand, which must have travelled in the air for more than 1000 miles ; this record was given in my " Geography of Victoria", p. 264.

I cannot determine the diatoms in Dr. Kidson's sample; but the character of the material is strikingly like that of the lake plains of Lakes Eyre, Callabonna, etc., in South Australia, and fully supports Mr. Kidson's conclusions. This record is of interest not only as of another occurrence of his widespread dust distribution, but also from his estimates of its quantity.

This red dust no doubt contributes to the red clay of the deep sea; but that material covers so vast an area, and often lies so far from any likely source of desert supply, that the abysmal red clay is probably 